\title{
Structural investigation of As-Se chalcogenide thin films with different compositions: formation, characterization and peculiarities of volume and near-surface nanolayers
}

\author{
O.Kondrat $^{1}$, R.Holomb $^{1}$, V.Mitsa $^{1}$, M.Veres $^{2}$, N.Tsud $^{3}$ \\ ${ }^{1}$ Institute of Solid State Physics and Chemistry, Uzhhorod National \\ University, 54 Voloshin Str., 88000 Uzhhorod, Ukraine \\ ${ }^{2}$ Wigner Research Centre for Physics, Hungarian Academy of Sciences, \\ 1121 Budapest, Hungary \\ ${ }^{3}$ Charles University, Faculty of Mathematics and Physics, Department of \\ Surface and Plasma Science, 2 V.Holesovickach Str., 18000 Prague 8, \\ Czech Republic
}

Received April 24, 2017

\begin{abstract}
$\mathrm{As}_{20} \mathrm{Se}_{80}, \mathrm{As}_{40} \mathrm{Se}_{60}$ and $A s_{50} \mathrm{Se}_{50}$ films were studied by Raman spectroscopy in order to examine the local- and medium-range order of the structure. In addition, X-ray photoelectron, Raman and surface enhanced Raman spectroscopy were used to characterize the structural peculiarities at the top surface of As-Se nanolayers. Raman investigations reveal the dominance of the $\mathrm{As}_{2} \mathrm{Se}_{3}$ and $\mathrm{As}_{4} \mathrm{Se}_{4}$ molecules in the volume of the $\mathrm{As}_{40} \mathrm{Se}_{60}$ and $A s_{50} \mathrm{Se}_{50}$ films and significant contribution of $\mathrm{Se}$ in the structure of the $\mathrm{As}_{20} \mathrm{Se}_{80}$ film. The composition and local structure of the surfaces were determined by curve fitting of the experimental X-ray photoelectron As $3 d$ and Se $3 d$ core level spectra. A significant Se-enrichment was found at the near-surface layers in comparison with the composition of deeper layers which is confirmed by the dominance of As-3Se structural units in all compositions. This enrichment was also observed by surface enhanced Raman spectroscopy. Processes of arsenic oxidation and desorption of the oxidized products are impacting the structure of the surface layers of $A s_{20} \mathrm{Se}_{80}, \mathrm{As}_{40} \mathrm{Se}_{60}$ and $A s_{50} \mathrm{Se}_{50}$ films.

Keywords: chalcogenide glass, amorphous film, As-Se nanolayers, X-ray photoelectron spectra, surface enhanced Raman spectra, structural units.

Пленки $\mathrm{As}_{20} \mathrm{Se}_{80}, \mathrm{As}_{40} \mathrm{Se}_{60}$ и $\mathrm{As}_{50} \mathrm{Se}_{50}$ исследованы с помощью спектроскопии комбинационного рассеяния с целью изучения структуры ближнего и среднего порядка. Кроме того, рентгеновская фотоэлектронная спектроскопия и поверхностно усиленная спектроскопия комбинационного рассеяния света использованы для характеризации структурных особенностей приповерхностных нанослоев As-Se. Исследование Раманспектров показывает доминирование молекул $\mathrm{As}_{2} \mathrm{Se}_{3}$ и $\mathrm{As}_{4} \mathrm{Se}_{4}$ в объеме пленок $\mathrm{As}_{40} \mathrm{Se}_{60}$ и $\mathrm{As}_{50} \mathrm{Se}_{50}$ и значительный вклад $\mathrm{Se}$ в структуру пленки $\mathrm{As}_{20} \mathrm{Se}_{80}$. Состав и локальная структура поверхности определены с помощью аппроксимации экспериментальных спектров основных уровней As $3 d$ и Se $3 d$. Показано, что имеет место существенное селенообогащение поверхности по сравнению с составом глубоких слоев, что подтверждается преобладанием структурных единиц As-3Se во всех составах. Это обогащение также подтверждено поверхностно усиленной Раман спектроскопией. Процессы окисления мышьяка и десорбции продуктов окисления влияют на структуру поверхностных слоев пленок $\mathrm{As}_{20} \mathrm{Se}_{80}, \mathrm{As}_{40} \mathrm{Se}_{60}$ и $\mathrm{As}_{50} \mathrm{Se}_{50}$.
\end{abstract}


Структурні дослідження плівок халькогенідів As-Se різної композиції: формування, характеризація і особливості об'єму та приповерхневих наношарів. О.Кондрат, Р.Голомб, В.Міца, М.Вереш, Н.Цуд.

Плівки $\mathrm{As}_{20} \mathrm{Se}_{80}, \mathrm{As}_{40} \mathrm{Se}_{60}$ i $\mathrm{As}_{50} \mathrm{Se}_{50}$ досліджено за допомогою спектроскопії комбінаційного розсіювання з метою вивчення структури ближнього і середнього порядку. Крім того, рентгенівську фотоелектронну спектроскопію і поверхнево підсилену спектроскопію комбінаційного розсіювання світла використано для характеризації структурних особливостей приповерхневих наношарів As-Se. Дослідження Раман-спектрів показують домінування молекул $\mathrm{As}_{2} \mathrm{Se}_{3}$ та $\mathrm{As}_{4} \mathrm{Se}_{4}$ у об'ємі плівок $\mathrm{As}_{40} \mathrm{Se}_{60}$ і $\mathrm{As}_{50} \mathrm{Se}_{50}$ та значний вклад $\mathrm{Se}$ у структуру плівки $\mathrm{As}_{20} \mathrm{Se}_{80}$. Склад i локальну структуру поверхні визначено за допомогою апроксимації експериментальних спектрів основних рівнів As $3 d$ i Se $3 d$. Показано, що має місце суттєве селенозбагачення поверхні у порівнянні зі складом глибших шарів, що підтверджується домінуванням структурних одиниць As3Se y всіх композиціях. Це збагачення також було підтверджено поверхнево підсиленою Раман спектроскопією. Процеси окислення миш'яку і десорбції окислених продуктів впливають на структуру поверхневих шарів плівок $\mathrm{As}_{20} \mathrm{Se}_{80}, \mathrm{As}_{40} \mathrm{Se}_{60}$ i $\mathrm{As}_{50} \mathrm{Se}_{50}$.

\section{Introduction}

Arsenic selenide glasses are among the most important glassy chalcogenide materials useful for many different applications in infrared (IR) optics, data recording, imaging, sensing and recently in chalcogenide photonics. Stoichiometric $\mathrm{As}_{2} \mathrm{Se}_{3}$ is a classic glass former and also has the interesting feature of having a composition exactly at the floppy-to-rigid transition [1]. Different $\mathrm{As}_{x} \mathrm{Se}_{100-x}$ materials have special interest because of their opto-mechanical properties [2].

Amorphous films of $\mathrm{As}_{x} \mathrm{Se}_{100-x}$ chalcogenide glass (ChG) system are currently of interest as materials for optoelectronic devices as well as optical information storage $[3,4]$. It was found that $\mathrm{As}_{50} \mathrm{Se}_{50}$ exhibits high light sensitivity during photostructural transformations due to the presence of homopolar As-As bonds [5, 6]. The excess of As in $\mathrm{As}_{50} \mathrm{Se}_{50}$ relative to stoichiometric $\mathrm{As}_{40} \mathrm{Se}_{60}$ leads to an increase of the optical gap $E_{g}$ (from 1.90 to $1.95 \mathrm{eV}$ for bulk $\mathrm{As}_{40} \mathrm{Se}_{60}$ and $\mathrm{As}_{50} \mathrm{Se}_{50}$, respectively) [7]. The evaporated films have been shown to have a large degree of structural disorder which was found to depend on the method and conditions used for deposition [8]. In addition to structural disorder of the amorphous state connected with the absence of long range order and translation symmetry, the two types of defects: (i) coordination defects (i.e. so called charged $D^{+}$and $D^{-}$ centers or valence-alternation pairs (VAPs)) and (ii) homopolar bonds defects (sometimes referred to as "wrong bonds") can be found in non-crystalline structures, too [9]. VAPs in the $\mathrm{As}_{2} \mathrm{Se}_{3}$ glass have been detected by Antoine et al. using X-ray photoelectron spectroscopy (XPS) and first principles mo- lecular dynamics simulations. Also, it was found that the concentration of such defects decreases upon near bandgap laser irradiation [10]. On the other hand, the concentration of homopolar bonds in arsenic chalcogenides was estimated to be $\sim 10^{2}-10^{3}$ times larger than that of the charged defects [11]. The role of charged defects in the structure and properties of oxy-chalcogenide glasses were also discussed in [12].

The dimensions of active elements in modern opto-electronic and photonic devices are in the order of nanometers. Therefore the role of the material surface became very important. Also, the local structure and structural defects (both charged defects and/or homopolar bonds) normally occurring at the surface contribute also to the general (bulk) electronic, optical and other physico-chemical properties of ultrasmall active chalcogenide elements $[13,14]$. Thus, the characterization of the local structure at the surface of deposited nanolayers and the study of their relationship with the physico-chemical properties are of great scientific importance from both fundamental and applied points of view.

The XPS with a sampling depth of approximately few monolayers $(\sim 30$ angstroms) is an excellent method to study surface properties of materials [15]. In this paper the XPS spectroscopy was used to characterize atomic composition and shortrange order at the surface of $\mathrm{As}_{20} \mathrm{Se}_{80}$, $\mathrm{As}_{40} \mathrm{Se}_{60}$ and $\mathrm{As}_{50} \mathrm{Se}_{50}$ nanolayers. Additional (medium-range order, cluster and molecular structure) structural information of As-Se nanolayers were obtained by Raman spectroscopy which was used in both ordinary and surface enhanced regimes. The surface-enhanced Raman spectroscopy 


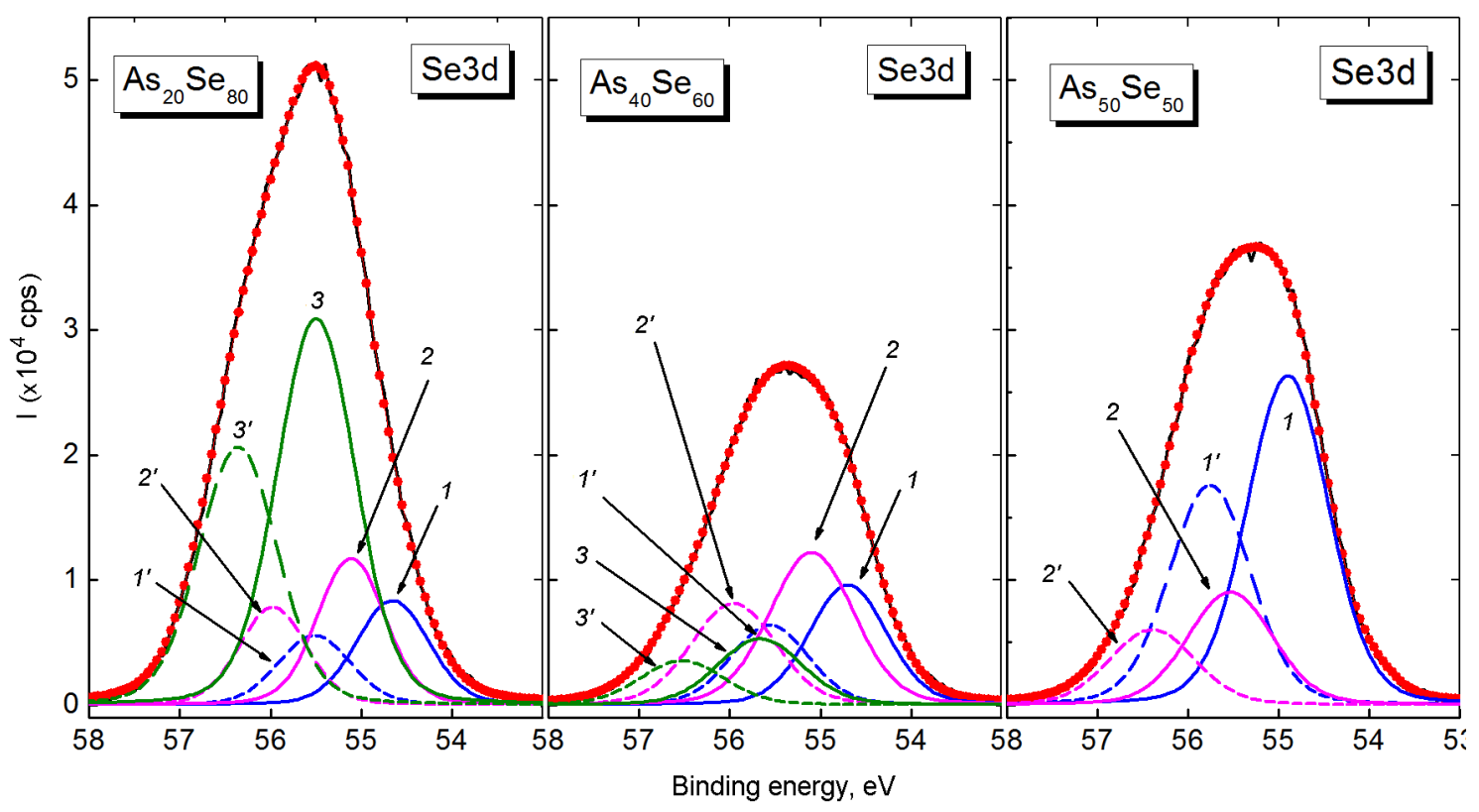

Fig. 1. XPS Se $3 d$ core level spectra of $\mathrm{As}_{x} \mathrm{Se}_{100-x}(x=20,40,50)$ films together with the results of curve fitting. Peak components were identified as Se-2As (1), Se-1Se1As (2), Se-2Se (3). 1, 2, 3 denote $3 d_{5 / 2}$ peaks, and $1^{\prime}, 2^{\prime}, 3^{\prime}$ denote $3 d_{3 / 2}$ peaks. (Color on-line).

(SERS) allows us to examine the structure of the nanolayer surface. The aim of this work is the examination of the atomic stoichiometry, local- and medium-range order structures and their characteristics as well as electronic properties of the surfaces of deposited As-Se nanolayers.

\section{Experimental}

$X P S$ and Raman spectroscopy of As-Se nanolayers

Amorphous As20Se80, As40Se60 and As50Se50 thin films with thickness of about $500 \mathrm{E}$ were prepared by thermal evaporation of source bulk glasses onto (100) silicon crystal wafer substrates. The bulk $A s_{x} S_{100-x}$ $(\mathrm{x}=20,40,50)$ samples were prepared by the conventional melt-quenching route in evacuated quartz ampoules from a mixture of high purity $99.999 \%$ As and Se precursors [16]. The furnace was rocked to obtain the most homogeneous melt. All ingots were quenched by switching off the furnace.

Photoemission measurements were performed with a $\mathrm{Mg} \mathrm{K}_{\alpha}(h v=1253.6 \mathrm{eV}) \mathrm{X}$-ray source. As $3 d$ and Se $3 d$ core levels were recorded at normal emission geometry [17]. This method is surface sensitive and allows to analyze the near-surface part of the film $(\sim 2 \mathrm{~nm})$ [18]. The C $1 s$ core-level spectra of all As-Se films were measured and the binding energy (BE) of the C $1 s$ signal from surface impurities $(285.0 \mathrm{eV})$ was used for preliminary energy correction, and was crosschecked using the $\mathrm{BE}$ of the Se $3 d_{5 / 2}$ bulk signal $(55.6 \mathrm{eV})[19,20]$. To accommodate the differences in surface potentials between samples, and to determine the absolute positions of all XPS core levels, an ultrathin $(\sim 3 \AA)$ gold film was deposited on the sample surface. Then the experimental positions of the core levels for all the investigated samples were also calibrated by referencing to the $4 f_{7 / 2}$ core level peak of pure $\mathrm{Au}$ at $84.0 \mathrm{eV}$ [20]. The gold-deposited sample was used only for the determination of absolute position and for controlling the studied core level shapes. The measured intensities of As $3 d$ and Se $3 d$ core level spectra were normalized by the corresponding atomic photoionization cross-sections [17]. The Se $3 d$ and As $3 d$ core level peaks were fitted using a Voigt function with subtraction of a Shirley type background to yield peak position and intensity. The fitting procedure is described elsewhere in detail [21].

Raman spectra were measured using a Renishaw system 1000 Raman spectrometer, equipped with a CCD detector. A diode laser operating at $785 \mathrm{~nm}$ was used as the excitation source. The measurements were made in micro-Raman configuration using backscattering geometry. In order to avoid the photo-induced changes in the structure of the samples, stimulated by this laser, the output power of the excitation source was 


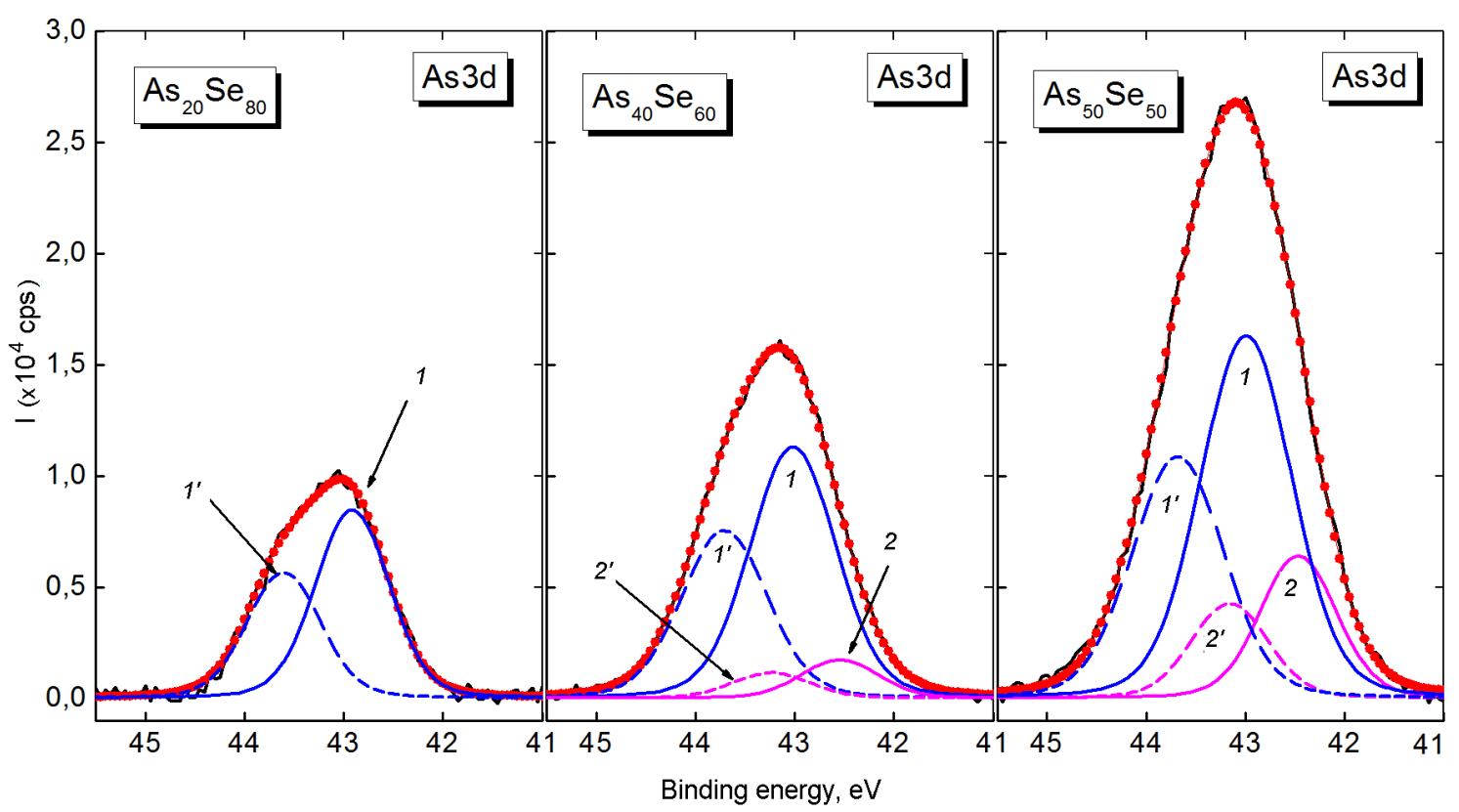

Fig. 2. XPS As $3 d$ core level spectra of $A_{x} S_{100-x}(x=20,40,50)$ films together with the results of curve fitting. Peak components were identified as As-3Se (1), As-2Se1As (2). 1, 2, denote $3 d_{5 / 2}$ peaks, and $1^{\prime}, 2^{\prime}$, denote $3 d_{3 / 2}$ peaks. (Color on-line).

limited by means of optical filters [22]. The ordinary Raman spectroscopy gives integral structural information on the As-Se films (from the surface and deeper subsurface layers, up to few micrometers) at medium range order scale. To distinguish between surface and subsurface structure of the AsSe nanolayers, SERS measurements have been performed as well. For this reason, $20 \mathrm{~nm}$ gold nanoparticles were placed on the surface of the films and were used to activate the surface enhancement in the Raman spectra of As-Se nanolayers. In the SERS spectra the signal from the surface is essentially stronger and this allows to distinguish between the integral and the surface (few nanometers) Raman signal and to perform the structural analysis of the surface part of samples.

\section{Results and discussion}

Results of the XPS measurements of the $\mathrm{As}_{20} \mathrm{Se}_{80}, \mathrm{As}_{40} \mathrm{Se}_{60}$ and $\mathrm{As}_{50} \mathrm{Se}_{50}$ thin films together with the results of curve fitting are shown in Fig. 1 and 2. As seen from Fig. 1, the Se $3 d$ core level spectra of the $\mathrm{As}_{20} \mathrm{Se}_{80}$ and $\mathrm{As}_{40} \mathrm{Se}_{60}$ thin films were fitted well using 3 doublets with $3 d_{5 / 2}$ spinorbit splitting components at $\sim 54.7 \mathrm{eV}$ (peak 1), $\sim 55.2 \mathrm{eV}$ (peak 2) and $\sim 55.5 \mathrm{eV}$ (peak 3) binding energies. According to the published data, peak 3 is assigned to $\mathrm{Se}-$ $2 \mathrm{Se}$ s.u. in bulk Se [20]. The averaged mo- lecular orbital (MO) energy level of the Se $3 d$ core level calculated for this s.u. of $55.7 \mathrm{eV}[23]$ is a further confirmation of this assignment. DFT calculations show that the substitution of Se by As leads to an energy shift of the Se $3 d$ core level to $55.3 \mathrm{eV}$ for an Se-1Se1As s.u. and to $54.8 \mathrm{eV}$ for an Se-2As s.u. [23]. Therefore, we assigned peak $2(55.2 \mathrm{eV})$ in the Se $3 d$ core level spectra of the $\mathrm{As}_{20} \mathrm{Se}_{80}$ and $\mathrm{As}_{40} \mathrm{Se}_{60}$ thin films to Se-rich As-Se-Se s.u. The calculated energy of $54.8 \mathrm{eV}$ coincides well with the experimental Se $3 d$ core level $\mathrm{BE}$ of $54.7 \mathrm{eV}$ found for the $\mathrm{As}_{2} \mathrm{Se}_{3}$ crystal in which only the Se-2As s.u. is present $[19,20]$. This component becomes the most intense in the Se $3 d$ core level spectrum of the $\mathrm{As}_{50} \mathrm{Se}_{50}$ sample (see Fig. 1). In addition, there is no peak 3 in the Se $3 d$ core level this sample.

The As $3 d$ core level spectrum of the $\mathrm{As}_{50} \mathrm{Se}_{50}$ thin film (Fig. 2) was fitted using two components assigned to arsenic bonded to three selenium atoms (As-3Se s.u., $\sim 42.9 \mathrm{eV}$, peak 1) and arsenic bonded to two selenium and one arsenic atoms (As-2Se1As s.u., $\sim 42.5 \mathrm{eV}$, peak 2); these energies are in good agreement with values reported for materials with corresponding arsenic chemical coordination: $\mathrm{As}_{2} \mathrm{Se}_{3}$, and realgar-type $\mathrm{As}_{4} \mathrm{Se}_{4}$, respectively [20,24-27]. The calculated MO energy of the As $3 d$ core level components for units where Se was substituted 
Table 1. Atomic concentrations and As/Se ratio of $\mathrm{As}_{20} \mathrm{Se}_{80}, \mathrm{As}_{40} \mathrm{Se}_{60}$ and $\mathrm{As}_{50} \mathrm{Se}_{50}$ films calculated from XPS data. For comparison, the values of As/Se ratio for the bulk glasses are given in parentheses.

\begin{tabular}{|c|c|c|c||}
\hline & $\mathrm{As}_{20} \mathrm{Se}_{80}$ & $\mathrm{As}_{40} \mathrm{Se}_{60}$ & $\mathrm{As}_{50} \mathrm{Se}_{50}$ \\
\hline $\mathrm{As}, \%$ & 13.1 & 23.8 & 38.1 \\
\hline $\mathrm{Se}, \%$ & 86.9 & 76.2 & 61.9 \\
\hline $\mathrm{As} / \mathrm{Se}$ & $0.15(0.25)$ & $0.31(0.67)$ & $0.62(1.0)$ \\
\hline
\end{tabular}

by $\mathrm{As}$ in $\mathrm{AsSe}_{3}$ pyramids, i.e. As-2Se1As and As-3Se, is overestimated by about $\sim 0.7 \mathrm{eV}$ [23] but in general are in good agreement with the experimental data. The same components were found for the As $3 d$ core level spectra of the $\mathrm{As}_{40} \mathrm{Se}_{60}$ film. Finally, the As $3 d$ core level spectra of $\mathrm{As}_{20} \mathrm{Se}_{80}$ were fitted by a single As-3Se component only, which is expected for the As-poor composition.

The Raman and SERS spectra of As-Se nanolayers are shown in Fig. 3 and Fig. 4, respectively. Raman spectra of the $\mathrm{As}_{40} \mathrm{Se}_{60}$ and $\mathrm{As}_{50} \mathrm{Se}_{50}$ thin films are similar to each other and are characterized by the main peak at $220 \mathrm{~cm}^{-1}$ with a shoulder at $252 \mathrm{~cm}^{-1}$. The $\mathrm{As}_{20} \mathrm{Se}_{80}$ composition demonstrates the dominance of the band at the $252 \mathrm{~cm}^{-1}$ and the presence of an inflection at $220 \mathrm{~cm}^{-1}$. Apart from that all spectra contain a small peak at $130 \mathrm{~cm}^{-1}$. The band at $300 \mathrm{~cm}^{-1}$ is related to the signal from the Si substrate. SERS spectra of the investigated samples are characterized by the intensive peak at $247 \mathrm{~cm}^{-1}$, which is sharp for the $\mathrm{As}_{20} \mathrm{Se}_{80}$ and $\mathrm{As}_{40} \mathrm{Se}_{60}$ compositions and significantly wider for the $\mathrm{As}_{50} \mathrm{Se}_{50}$ film. In the lower frequency region peaks were detected at 105, 125, 165 and $187 \mathrm{~cm}^{-1}$. Atomic stoichiometry

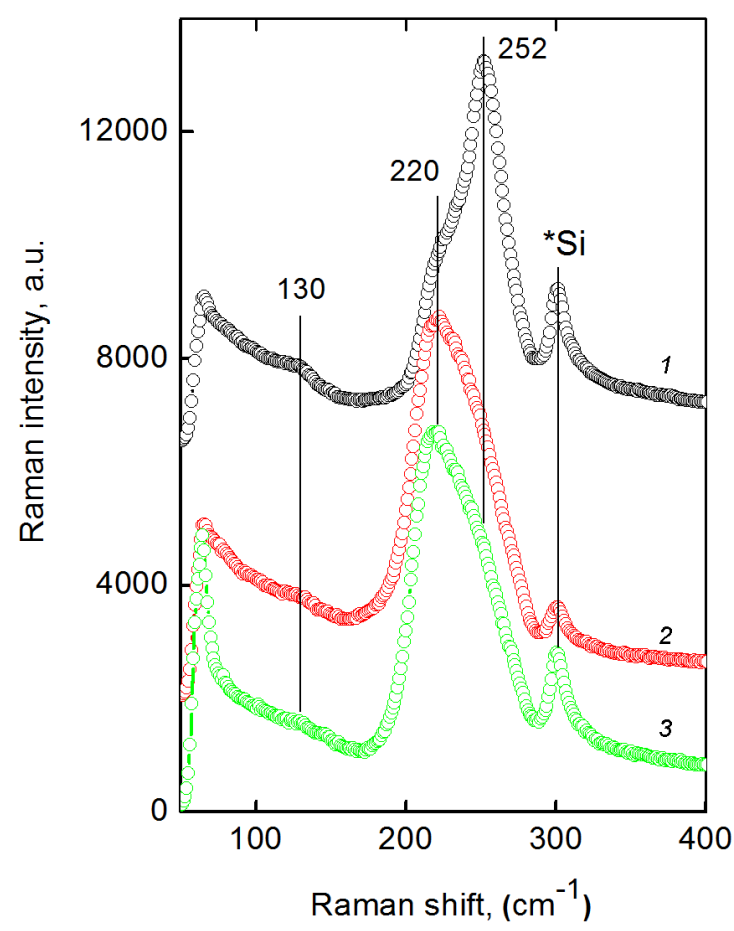

Fig. 3. Raman spectra of $\mathrm{As}_{x} \mathrm{Se}_{100-x}$ films: 1) $x=20$;2) $x=40$; 3) $x=50$.

To analyze the composition of the surface nanolayers, the atomic concentrations and As to-Se ratio of the films under investigation were calculated using As $3 d$ and Se $3 d$ peak areas normalized to appropriate cross sections (see Table 1). The significant loss of As content is evident for all $\mathrm{As}_{x} \mathrm{Se}_{100-x}$ films. Similar depletion of the As content was detected in our earlier synchrotron radiation photoelectron spectroscopy (SRPES) study of As-Se nanolayers using the excitation energy of $450 \mathrm{eV}[16,21]$. The drastic loss of As at the surface of the two As-rich $\mathrm{As}_{40} \mathrm{Se}_{60}$ and $\mathrm{As}_{50} \mathrm{Se}_{50}$ compositions can be connected with the presence of homopolar As-As bonds in their structure.

Table 2. Contribution (Area, $\pm 5 \%$ ) to the main $\left(3 d_{5 / 2}\right)$ peak of each doublet of individual components determined from curve fitting of Se $3 d$ and As $3 d$ XPS spectra of $A_{20} \mathrm{Se}_{80}, \mathrm{As}_{40} \mathrm{Se}_{60}$ and $\mathrm{As}_{50} \mathrm{Se}_{50}$ films

\begin{tabular}{||c|c|c|c||}
\hline Core level/Component & $\mathrm{As}_{20} \mathrm{Se}_{80}$ & $\mathrm{As}_{40} \mathrm{Se}_{60}$ & $\mathrm{As}_{50} \mathrm{Se}_{50}$ \\
\hline Se 3d: & & & 72.9 \\
Se-2As, \% & 15.8 & 33.5 & 27.1 \\
$\mathrm{Se}-1 \mathrm{Se}$ As, \% & 20.7 & 46.4 & - \\
Se-2Se, \% & 63.5 & 20.1 & 24.8 \\
\hline As 3d: & - & & 75.2 \\
\hline As-2Se1As, \% & 100 & 82.1 & 17.9 \\
As-3Se, \%
\end{tabular}


These weak As-As bonds can easily break on the surface under the influence of ambient conditions (i.e. oxidation etc.) [16, 21]. The oxidation of As leads to formation of $\mathrm{As}_{2} \mathrm{O}_{3}$ at the surface [28]. The desorption of volatile arsenic oxides from the near-surface layers [29] can explain the drastic loss of As content.

The $\mathrm{As}_{2} \mathrm{Se}_{3}$ characterized by layered structure formed by As-Se rings built from As-3Se pyramids. Such a 2D network can be considered as a "protective network" which slows down the oxidation processes in deeper layers of the film. The $\mathrm{As}_{50} \mathrm{Se}_{50}$ composition does not form a $2 \mathrm{D}$ network and represents mostly a molecular-like structure with $\mathrm{As}_{4} \mathrm{Se}_{4}$ and/or $\mathrm{As}_{4} \mathrm{Se}_{3}$ units. The structure of the $\mathrm{As}_{20} \mathrm{Se}_{80}$ film is also formed mostly by 1D structures (-Se-Se-Se-chains) and $\mathrm{Se}_{8}$ molecules. Such structural characteristics of the $A s_{20} \mathrm{Se}_{80}$ and $\mathrm{As}_{50} \mathrm{Se}_{50}$ films explain the higher level of oxidation of arsenic in deeper layers, which, together with the diffusion of the oxidized arsenic to the surface region and its desorption in the form of $\mathrm{As}_{2} \mathrm{O}_{3}$ causes the As-loss [23, 29].

Component analysis

The contributions of the Se $3 d$ and As $3 d$ peak components to the total core level intensity is shown in Table 2. The main component of the Se $3 d$ peak of $\mathrm{As}_{20} \mathrm{Se}_{80}$ sample is the Se-2Se s.u., with a significant contribution of the Se-1Se1As s.u. $(20.7 \%)$ and Se-2As s.u. (15.8\%). Taking into account the As $3 d$ core level of this structure with a single As-3Se component, it can be concluded that there are no homopolar As-As bonds on the surface of $\mathrm{As}_{20} \mathrm{Se}_{80}$ nanolayers, i.e. each arsenic atom is bonded only with selenium atoms.

Homopolar As-As bonds appear in the $\mathrm{As}_{40} \mathrm{Se}_{60}$ film: the As $3 d$ core level contains $17.9 \%$ of As-2Se1As s.u. in addition to $82.1 \%$ of the As-3Se s.u. In contrast to $\mathrm{As}_{20} \mathrm{Se}_{80}$, curve fitting of the Se $3 d$ spectrum of $\mathrm{As}_{40} \mathrm{Se}_{60}$ shows the redistribution in the peak component intensities: the most intensive component becomes Se-1Se1As. These results show a significant difference between the structure of $\mathrm{As}_{40} \mathrm{Se}_{60}$ surface nanolayers and the structure of $\mathrm{As}_{2} \mathrm{Se}_{3}$ crystal where only Se-2As s.u. (in Se $3 d$ ) and As-3Se s.u. (in As $3 d$ ) are expected. The stoichiometric (Se-2As) component dominates $(72.9 \%)$ the Se $3 d$ core level of the $\mathrm{As}_{50} \mathrm{Se}_{50}$ film. The concentrations of the other two components, Se-1Se1As and Se$2 \mathrm{Se}$, were calculated to be $26 \%$ and $0 \%$,

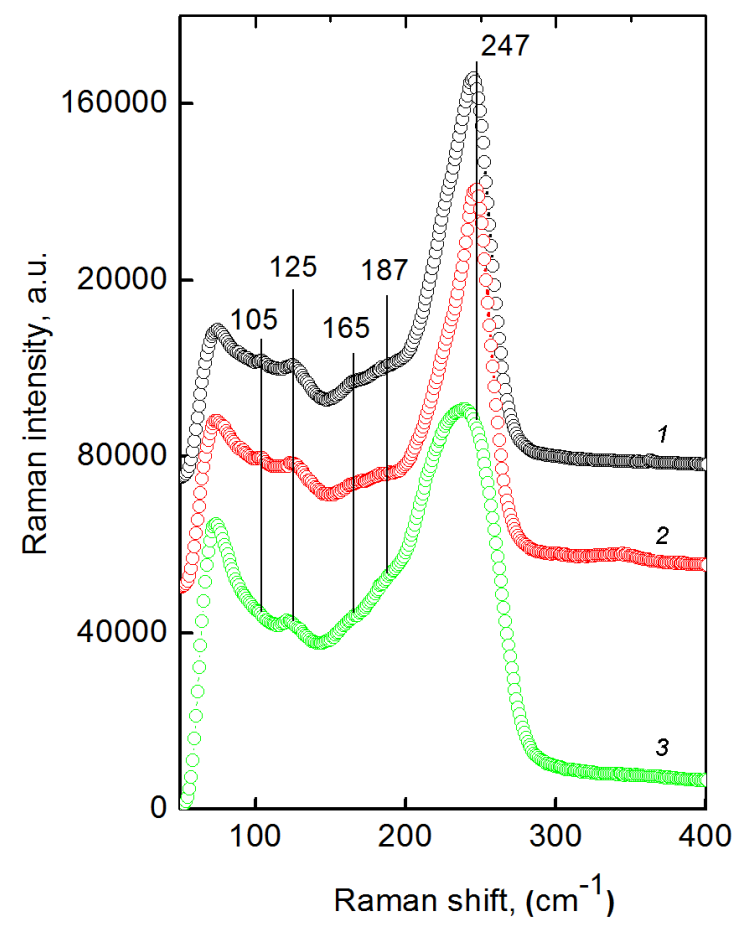

Fig. 4. Surface enhanced Raman spectra of As $\mathrm{Se}_{100-x}$ films: 1) $x=20$;2) $x=40$; 3) $x=$ 50 .

respectively. Simultaneously, the contribution of As-2Se1As s.u. in As $3 d$ core level of $\mathrm{As}_{50} \mathrm{Se}_{50}$ increases to $24.8 \%$ from $17.9 \%$ found for $\mathrm{As}_{40} \mathrm{Se}_{60}$.

Similar investigations have been made using synchrotron radiation as an excitation source to get a photoelectron spectra of the $\mathrm{As}_{x} \mathrm{Se}_{100-x}(x=20,40$ and 50$)$ surface nanolayers [23]. In this case, the sampling depth of the measured photoelectron is approximately 10 angstroms [30] in contrast to the $\sim 30$ angstroms for the XPS. The $\mathrm{As}_{20} \mathrm{Se}_{80}$ composition is characterized by the absence of the water-like Se-2As s.u. on surface layers. The types of structural units in $\mathrm{As}_{40} \mathrm{Se}_{60}$ sample are found to be the same for both cases and their contributions to the appropriate core levels (As $3 d$ and Se $3 d$ ) are quite similar. Finally, on the surface of the $\mathrm{As}_{50} \mathrm{Se}_{50}$ film some quantity $(18 \%)$ of Se-2Se s.u. was detected. Such fact correlates well with the $70 \%$ of Se, detected on the surface instead of the $62 \%$ in the deeper layers. All these data indicate the formation of the gradient concentration in the near surface layers of the $A s_{20} \mathrm{Se}_{80}$ and $\mathrm{As}_{50} \mathrm{Se}_{50}$ thin films: the surfaces of these films are enriched by structural units with homopolar Se-Se bonds. It can be a consequence of the desorption of some part of As atoms from the surfaces due to the weak- 
ness of As-As bonds. At the same time, the $\mathrm{As}_{40} \mathrm{Se}_{60}$ sample is the most homogeneous at least within the top $\sim 30$ angstroms.

Middle range order

Ping Chen et al. [31] discovered the aging of selenium and arsenic-selenide glasses with different composition and have analyzed the Raman spectra of crystalline $\mathrm{As}_{2} \mathrm{Se}_{3}, \mathrm{As}_{4} \mathrm{Se}_{4}$, and $\mathrm{As}_{4} \mathrm{Se}_{3}$. From this work it can be seen that the main peak in the Raman spectrum of the Se is located at $\sim 253 \mathrm{~cm}^{-1}$ and connected with the $\mathrm{Se}_{8}$ rings. The addition of As lead to formation of the new peaks in the Raman spectra of As-Se glasses located at lower wavenumbers. The Raman spectrum of the $c-\mathrm{As}_{2} \mathrm{Se}_{3}$ is characterized by the peaks at $\sim 247, \sim 230$, $\sim 216$ and $\sim 202 \mathrm{~cm}^{-1}$. Taking into account these data it can be argued that SERS spectra of the $\mathrm{As}_{20} \mathrm{Se}_{80}, \mathrm{As}_{40} \mathrm{Se}_{60}$ and $\mathrm{As}_{50} \mathrm{Se}_{50}$ thin films (see Fig. 4) demonstrate the dominance of selenium in the composition of the films. Such Se-enrichment correlates well with the results of the XPS investigations (see Table 1). It can be seen mostly for the $\mathrm{As}_{20} \mathrm{Se}_{80}$ and $\mathrm{As}_{40} \mathrm{Se}_{60}$ compositions. The broadening of the spectra in the lowfrequency part means the presence of some quantity of the arsenic. This broadening is the highest for the $\mathrm{As}_{50} \mathrm{Se}_{50}$ composition and correlates well with data presented in Table 1. The Raman spectrum of the $\mathrm{As}_{20} \mathrm{Se}_{80}$ film (Fig. 3) is similar to its SERS spectrum and confirms the dominance of Se in the structure of the film. The shape and position of peaks in the Raman spectra of $\mathrm{As}_{40} \mathrm{Se}_{60}$ and $A s_{50} \mathrm{Se}_{50}$ thin films are similar to those showed in [31] and demonstrate the presence of $\mathrm{As}_{2} \mathrm{Se}_{3}$ and $\mathrm{As}_{4} \mathrm{Se}_{4}$ molecules. Such differences between the results of Raman spectroscopy and SERS confirm the formation of the gradient concentration from the surface to the deeper layers of the films.

\section{Conclusions}

The surface of $\mathrm{As}_{20} \mathrm{Se}_{80}, \mathrm{As}_{40} \mathrm{Se}_{60}$ and $\mathrm{As}_{50} \mathrm{Se}_{50}$ nanolayers was studied in detail using X-ray photoelectron spectroscopy and surface enhanced Raman spectroscopy. Atomic concentrations and calculated As-toSe ratios obtained from photoelectron spectra show that all surfaces are enriched with chalcogen. Each sample demonstrates depth dependence (gradient) of arsenic content, which increases with the distance from the surface. The lowest deficiency of arsenic in the subsurface region was found in the $\mathrm{As}_{40} \mathrm{Se}_{60}$ sample, which was attributed to the 3D network-like structure of arsenic triselenide. The properties observed in the surface layers of $A s_{20} \mathrm{Se}_{80}, \mathrm{As}_{40} \mathrm{Se}_{60}$ and $\mathrm{As}_{50} \mathrm{Se}_{50}$ films are connected with both their molecular structure and processes of arsenic oxidation and desorption of the oxidized products. The Raman spectra of $\mathrm{As}_{40} \mathrm{Se}_{60}$ and $\mathrm{As}_{50} \mathrm{Se}_{50}$ films are different from the Raman spectrum of the $\mathrm{As}_{20} \mathrm{Se}_{80}$ film. However, the comparison of the Raman and SERS spectra of the samples shows that all film surfaces $\left(\mathrm{As}_{20} \mathrm{Se}_{80}\right.$, $\mathrm{As}_{40} \mathrm{Se}_{50}$ and $\left.\mathrm{As}_{50} \mathrm{Se}_{50}\right)$ are enriched by Se, as indicated by the main band at $247 \mathrm{~cm}^{-1}$ in the Raman spectra.

Component analysis shows the presence of structural units with homopolar Se-Se bonds and the stoichiometric Se-2As s.u. at the surface layers of all films, including also the As-rich composition. Free selenium (Se-2Se) structural units were detected in the structures of the $\mathrm{As}_{20} \mathrm{Se}_{80}$ and $\mathrm{As}_{40} \mathrm{Se}_{60}$ films. The stoichiometric Se-2As s.u. becomes dominant for the $\mathrm{As}_{50} \mathrm{Se}_{50}$ composition. In spite of the Se-enrichment of the sample surfaces, homopolar As-As bonds were detected in the structure of $\mathrm{As}_{40} \mathrm{Se}_{60}$ and $\mathrm{As}_{50} \mathrm{Se}_{50}$ films. Acknowledgments. O.K. and R.H. gratefully acknowledge support from the Hungarian Academy of Sciences within the Domus Hungarica Scientiarum et Artium Programme. N.T. acknowledges CERIC-ERIC consortium and Czech Ministry of Education (LM2015057) for financial support.

\section{References}

1. J.C.Phillips, J.Non-Cryst.Solids, 43, 37 (1981).

2. P.Krecmer, A.M.Moulin, R.J.Stephenson et al., Science, 277, 1799 (1997).

3. M.A.Iovu, M.S.Iovu, S.D.Shutov et al., J.Optoelec. Adv. Mat., 3, 473 (2001).

4. V.Aiyah, S.D.Kasap, B.Polischuk, A.Bailie, $J$. Non-Cryst. Solids, 164-166, 777 (1993).

5. V.M.Lyubin, J.Non-Cryst.Solids, 97-98, 47 (1987).

6. G.Pfeiffer, M.A.Paesler, S.G.Agarwal, J.NonCryst. Solids, 130, 111 (1991).

7. M.Hammam, G.J.Adriaenssens, W.Grevendonk, J.Phys.C:Solid State Phys., 18, 2151 (1985).

8. V.Mitsa, Doctoral Thesis, Institute of Semiconductors Physics, NAS of Ukraine, Kyiv (2003).

9. S.I.Simdyankin, T.A.Niehaus, G.Natarajan et al., Phys.Rev.Lett., 94, 086401(1-4) (2005).

10. K.Antoine, J.Li, D.A.Drabold et al., J.NonCryst. Solids, 326-327, 248 (2003). 
11. Ke.Tanaka, J.Optoelectron. Adv. Mater., 3, 189 (2001).

12. N.Terakado, Ke.Tanaka, Appl. Phys. Express, 1, 081501(1-3) (2008).

13. R.Holomb, N.Mateleshko, V.Mitsa et al., J. Non-Cryst. Sol., 352, 1607 (2006).

14. O.Kondrat, R.Holomb, A.Csik et al., Nanoscale Res. Lett., 12, 149 (2017).

15. S.Krishnaswami, H.Jain, A.C.Miller, J.Optoelect.Adv. Mat., 3, 695 (2001).

16. O.Kondrat, N.Popovich, R.Holomb et al., Thin Solid Films, 520, 7224 (2012).

17. J.J.Yeh, Atomic Calculation of Photoionization Cross-sections and Asymmetry Parameters, Gordon and Breach Science Publishers, Langhorne, PE (USA) (1993) and from J.J. Yeh and I. Lindau, Atomic Data and Nuclear Data Tables, 32, 1 (1985).

18. Choi Duk-Yong, M.Steve, R.Andrei et al., $J$. Appl. Phys., 102, 083532-5 (2007).

19. D.Briggs, M.P.Seah, Practical Surface Analysis, vol.1, 2nd ed., John Wiley \& Sons, New York, NY, USA (1993).

20. C.D.Wanger, W.M.Riggs, L.E.Davis et al., Handbook of X-ray Photoelectron Spectroscopy, Perkin-Elmer Corp., Physical Electron- ics Division, Eden Prairie, Minnesota, USA (1979).

21. O.Kondrat, N.Popovich, R.Holomb et al., J. Non-Cryst.Solids, 358, 2910 (2012).

22. O.Kondrat, N.Popovich, R.Holomb et al., Phys.Stat.Sol. C, 7, 893 (2010).

23. O.Kondrat, R.Holomb, N.Popovich et al., $J$. Non-Cryst. Solids, 410, 180 (2015).

24. P.R.Sarode, K.J.Rao, M.S.Hegd, C.N.R.Rao, J.Phys. C:Solid State Phys., 12, 4119 (1979).

25. T.Ueno, A.Odajima, Jpn.J.Appl.Phys., 20, L501 (1981).

26. T.Ueno, Jpn.J.Appl.Phys., 22, 1469 (1983).

27. M.K.Bahl, R.O.Woodall, R.L.Watson, K.J.Irgolic, J.Chem. Phys., 64, 1210 (1976).

28. T.N.Shchurova, N.D.Savchenko, A.B.Kondrat, I.I.Opachko, Surf. Interface Anal., 38, 448 (2006).

29. M.Janai, P.S.Rudman, F.Mandelbaum, J.NonCryst. Solids, 27, 67 (1978).

30. K.Antoine, H.Jain, M.Vlcek et al., Phys.Rev. $B$, 79, 054204(1-7) (2009).

31. Ping Chen, P.Boolchand, D.G.Georgiev, $J$. Phys. Condens. Matter, 22, 065104(16) (2010). 